\title{
DEFLECTION BEHAVIOR OF THE NAILED SLAB SYSTEM-SUPPORTED EMBANKMENT ON PEAT SOIL
}

\author{
Aazokhi Waruwu1 ${ }^{*}$ Hary Christady Hardiyatmo ${ }^{1}$ Ahmad Rifa' ${ }^{1}$ \\ ${ }^{1}$ Gadjah Mada University, Department of Civil and Environmental Engineering, Indonesia
}

Peat is one of the most problematic sub-soil foundation. It had high compressibility, low shear strength, and excessive and long-term settlement when subjected to imposed loads of construction. The efficient method for improvement of peat was preloading. It consists of applying a load in the form of the embankment. One of the alternatives for supported embankment construction was the use of nailed-slab system. A small-scale model laboratory research and settlement analysis were conducted to identify the effectiveness of nailed-slab system in reducing peat settlement due to the embankment. The research results indicated that the installation of piles on slabs was able to reduce the settlement of slabs and increase the modulus of sub-grade reaction. The performance of piles and slab were monolithically connected, it was more effective than non-monolithic piles.

Key words: Peat, Loads, Embankment, Pile

\section{INTRODUCTION}

The main characteristics of peat soil are high compressibility, low shear strength, and high moisture content [01]. Such characteristics pose problems if peat soil is used as a subgrade construction. Several methods to improve peat soil include soil replacement, reinforcement to improve soil strength and stiffness, preloading and stage construction, soil improvement, stone columns, piles, and mixing of chemicals such as cement and lime [02].

Sand fill on peat soil can improve parametric values of peat soil. Adding the thickness of sand on peat soil will increase the value of subgrade reaction modulus and the modulus of deformation [03]. Deposition of fill with better soil types can be performed on peat soil, but its implementation may encounter several problems. Some problems include excessive lateral movement, heave occurring on deposit of soft soil and the formation of mud wave, mixing of fill with the very soft soil, and differential settlement, as in [04]. The large deformation took place together with tension cracks and heave when the height of embankment rapidly increased [05].

Secondary settlement can be reduced by surcharging [06]. The effective method to improve peat soil are preloading and surcharging [07]. Preloading consists of applying a load, equivalent to or greater than a total load of a planned structure, over the site prior to constructing the structure which is being partially or fully removed when the required settlement has taken place. Preloading consisting of loading and unloading methods can accelerate peat soil compression [08]. The increase in OCR on loading and unloading methods for high organic soil can reduce the rate of secondary compression [09]. In addition to reducing compression, preloading can also increase the bearing capacity of peat [10]. The Embankment with stage construction and thin layers can be applied to peat soil to allow consolidation and increase shear strength.
Reinforcement can contribute to increasing the stability of embankment, that reinforcement and shear strength of peat will resist lateral forces [11]. Reinforcement with slabs without piles only affects the top layer of the surface with a depth of generally not more than the width of the foundation slab [12]. Slabs can be reinforced by piles to support the embankment. Some of the advantages of the piles in supporting embankment include the implementation of embankment construction can be completed in a short time, embankment-supporting piles can reduce total settlement and differential settlement significantly [13]. In addition, the implementation of the piles corresponds to non-uniform geological conditions.

Another alternative use of piles on soft soil is the use of nailed-slab system [14],[15],[16]. Piles affect the increase in modulus of subgrade reaction. The height of piles affects the stiffness of nailed-slab system and the reduction of slab deflection at the load center. The nailed-slab system generated uniform settlement, increased the strength of subgrade support, improved the ability to carry load and improved resistance to repeated load. Monolithic mini-piles with slabs can reduce the deformation of slabs without piles [14]. This system is expected to reduce the settlement and improve the stability of embankment on peat soil.

Based on the description above, it is necessary to employ preloading with stage load system of loading-unloading methods in order to reduce excessive settlement. In order that the stability of embankment load can be maintained, a slab reinforcement system supported by piles is required. This paper presents an interpretation of the reduction of settlement as a result of pile reinforcement, the connection between piles and slabs, and comparison between the results of consolidation settlement analysis and the observation. 


\section{ESTIMATION OF CONSOLIDATION SETTLEMENT}

The consolidation settlement for every stage of loading was estimated using Asaoka Method, hyperbolic method, and finite element method (FEM).

\section{Asaoka Method}

Final consolidation settlement and settlement at a given time could be estimated using Asaoka Method [17]. The stages in the settlement analysis using this method are selecting settlement $s_{1}$ to $s_{n}$ at time th and a constant time interval $\Delta t=t_{n}-t_{n-1}$, and then plotted $\left(s_{n}, s_{n-1}\right)$ where sn as ordinate and $s_{n-1}$ as abscissa. Constant $\beta_{1}$ is the slope of straight line curve and $\beta_{o}$ an intersection of linear line on the vertical axis of abscissa [18]. The final settlement is an intersection of the linear line from the relation of sn and $s_{n-1}$ with the $45^{\circ}$ line [19]. The final settlement of sf is expressed in Equation 1 and the settlement at time t (st) can be calculated by using Equation 2 [08].

$$
\begin{aligned}
& s_{f}=\frac{\beta_{o}}{1-\beta_{1}} \\
& s_{t}=s_{f}\left(1-\exp \left(\left(\ln \frac{\beta_{1}}{\Delta t}\right) t\right)\right)
\end{aligned}
$$

\section{Hyperbolic Method}

In addition to Asaoka Method, the hyperbolic method can be used to analyze field settlement in order to verify the results of observations. Tan et al. [20] proposed a hyperbolic relationship between field settlement $(s)$ and consolidation time $(t)$. The hyperbolic curve is obtained from Equation 3 , and the final settlement $\left(s_{f}\right)$ is defined from Equation 4.

$$
\begin{aligned}
& s=\frac{t}{\alpha+\beta t} \\
& s_{f}=\frac{1}{\beta}
\end{aligned}
$$

Where $\alpha$ and $\beta$ are intersection and slope of the linear line in the relation of ratio between $t / s$ as ordinate and $t$ as abscissa [18].

\section{Finite Element Method (FEM)}

The finite element modelling comprised two-dimensional plane strain analysis. It was carried out using PLAXIS [21]. Structure modelling for slabs with three rows of piles was modelled as plane strain. Circular pile cross-sectional shapes require idealization into the form of plane strain. The idealization of circular pile structure was transformed into continuous wall elements
(Figure 1). According to Ryltenius [22], such transformation of pile form will affect the value of normal stiffness, flexural rigidity, and pile weight. Continuous wall elements are defined per meter length; the normal stiffness for plane strain pile can be calculated by using Equation 5. Analogously, the flexural rigidity for plane strain pile is inputted as Equation 6, and the weight for plane strain pile as Equation 7.1 wide strip was taken as long as the pile spacing $\left(L_{r}=s\right) 0.1 \mathrm{~m}$ perpendicular pictures in a row of piles.

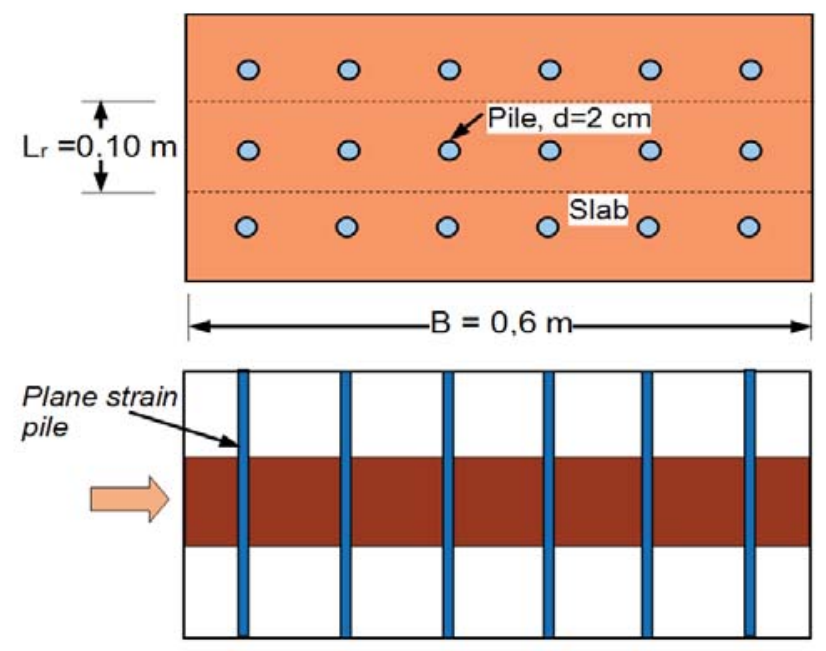

Figure 1: Plane strain model for slabs with three rows of piles

$$
\begin{aligned}
& E A_{p s p}=\frac{E A_{p}}{L_{r}} \\
& E I_{p s p}=\frac{E I_{p}}{L_{r}} \\
& w_{p s p}=\frac{w_{p}}{L_{r}}
\end{aligned}
$$

Where $E A_{P S D}$ is the normal stiffness for plane strain pile, $E A_{p}$ is the normal stiffness for one pile, $L_{r}$ is the pile spacing, $E_{\text {lpsp }}$ is the flexural rigidity for plane strain pile, $E_{l p}$ is the flexural rigidity for one pile, wpsp is the weight for plane strain pile, and wp is the weight for one pile.

\section{RESEARCH METHODS}

The peat soil used in this study were taken from Bagansiapiapi - Riau. Peat used was the same as the research materials of [08]. The test results of physical properties of peat soil were specific gravity $G_{s}=1.34$, bulk density $\gamma_{b}=10.75 \mathrm{kN} / \mathrm{m}^{3}$, moisture content $\mathrm{w}=970.86 \%$, organic content $O_{c}=99 \%$, fiber content $F_{c}=35.21 \%$, and ash 
content $A_{c}=1 \%$. Soil samples tested were fibrous peat because they had an organic content of $>75 \%$ and fiber content of $>20 \%$. Sorted peat samples were compacted in the test boxes every $10 \mathrm{~cm}$ in thickness with density close to the field conditions [08].

A preliminary test on single piles consisted of load test on slabs without piles and with piles. The concrete had a diameter of $10 \mathrm{~cm}$ and thickness of $2 \mathrm{~cm}$, while the piles had a diameter of $2 \mathrm{~cm}$ and length of $15 \mathrm{~cm}$ to $35 \mathrm{~cm}$. Besides this type of test, loading test on plate bearing without supporting pile was carried out using concrete slab sized $60 \mathrm{~cm} \times 28 \mathrm{~cm}$. The load on the loading test used iron bars with a weight according to the need. 50 $\mathrm{mm}$ capacity dial gauge with an accuracy of $0.01 \mathrm{~mm}$ was used to measure the amount of deformation due to the load on certain points.

Embankment load test model with laboratory small scale used box testing. The box shape and loading test were shown in Figure 2. The thickness of peat layer $\mathrm{H}=50$ $\mathrm{cm}$, and the rest was filled with firm soil. Cross sections and testing plan can be seen in Figure 3. Tests were conducted on five different tests including slabs without piles, slabs with monolithic and non-monolithic piles with a length $L_{p}=15 \mathrm{~cm}$ and $35 \mathrm{~cm}$. Slabs and piles were made of concrete materials, where the slabs had a thickness $t=2 \mathrm{~cm}$ and area of $60 \times 28 \mathrm{~cm}^{2}$, while the piles had a diameter of $d=2 \mathrm{~cm}$ cast monolithically or non-monolithically on the slabs with a distance between center to center of $s=10 \mathrm{~cm}$.

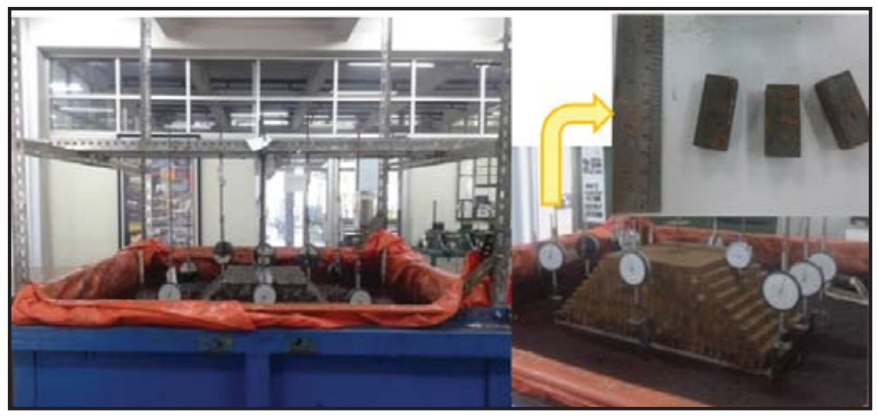

Figure 2: Laboratory small-scale model for embankment load test

Embankment load was supported by slabs with and without piles on peat soil layer. To produce a significant settlement, the embankment load was modelled from iron bars material sized $19 \mathrm{~mm} \times 19 \mathrm{~mm}$ with the lengths of $400 \mathrm{~mm}$ placed on the surface of peat soil (Figure 2). The unit weight of iron bars $(\gamma)$ was approximately $71.62 \mathrm{kN} /$ $\mathrm{m}^{3}$. One layer of the embankment load was given as high as of $h=38 \mathrm{~mm}$, equivalent to the pressure $(\sigma)$ of 2.72 $\mathrm{kPa}$. Slabs without piles were tested gradually every day until five layers of embankment load, while slabs with piles were tested using the loading-unloading system, where reloading was done after one day. Each loading and unloading required reading of the settlement from dial gauge installed in the middle of the slab and some other points.

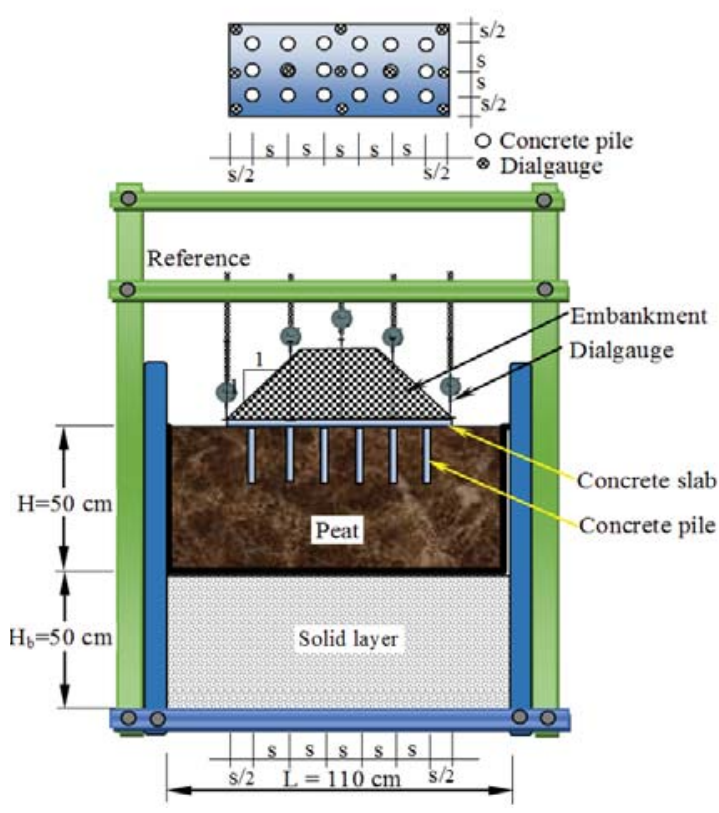

Figure 3: Test scheme in the laboratory

\section{RESULTS AND DISCUSSION}

The preliminary tests consisted of tensile load test on single piles to obtain pile frictional resistance, followed by load test on the concrete slab with a diameter of $10 \mathrm{~cm}$ with piles and without piles in order to determine the ratio of deflection of slabs with and without piles. The results of embankment load test supported by slabs with and without pile groups accompanied by settlement analysis employed several methods, including Asaoka method, hyperbolic method, and FEM.

\section{Single Pile Test Results}

The results of tensile test are shown in Figure 4, the tested piles had a length of $15 \mathrm{~cm}, 20 \mathrm{~cm}$ and $25 \mathrm{~cm}$. The value of maximum frictional resistance (fs) was approximately $0.86 \mathrm{kN} / \mathrm{m}^{2}$ obtained on piles with a length of $20 \mathrm{~cm}$.

\section{Unit friction, $\mathrm{f}_{\mathrm{s}}(\mathrm{kPa})$}

\section{$\begin{array}{lllllllllll}0 & 0,1 & 0,2 & 0,3 & 0,4 & 0,5 & 0,6 & 0,7 & 0,8 & 0,9 & 1\end{array}$}

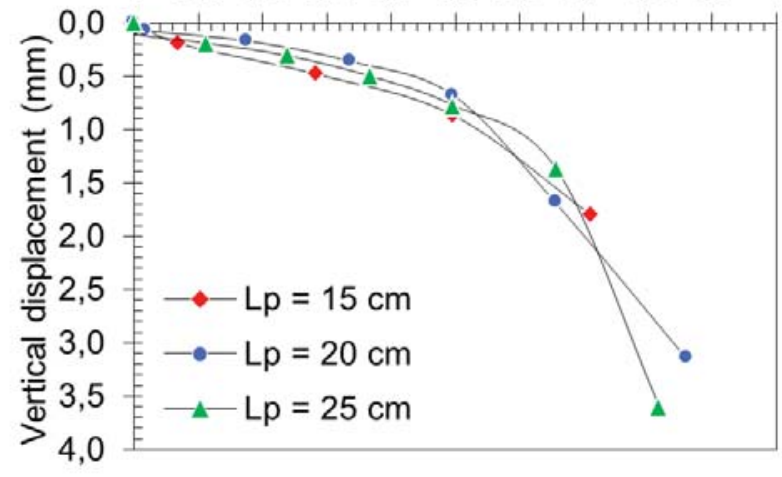

Figure 4: The results of pile tensile test on peat soil 
The test result of slabs with a diameter of $10 \mathrm{~cm}$ without piles and with piles $L_{p} 15 \mathrm{~cm}, 20 \mathrm{~cm}, 25 \mathrm{~cm}$, and $35 \mathrm{~cm}$ can be seen in Figure 5. According to Hardiyatmo [15], the ratio of $\delta / \delta_{0}$ on clay is taken at a constant curve, but on peat showed continuous compression and does not stop within a short time. Therefore, the ratio of $\delta / \delta_{0}$ is modified by taking the value at the intersection of linear line with a curve. In this research, the ratio of $\delta / \delta_{0}$ was close to constant at 0.31 with a deflection of $0.045 \mathrm{~m}$.

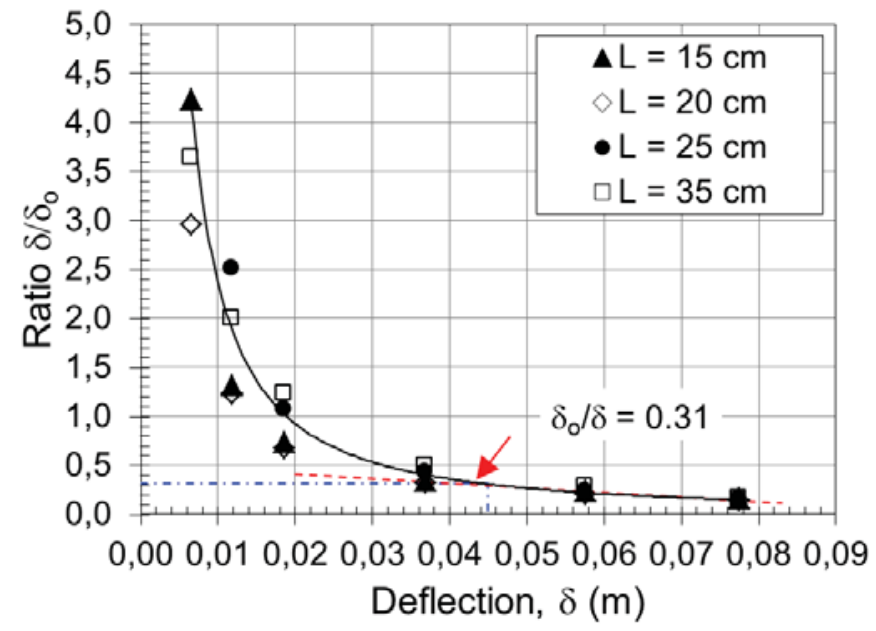

Figure 5: The relationship between the deflection of slabs $(\delta)$ and the ratio of $\delta / \delta_{0}$

\section{Modulus of Subgrade Reaction}

Structural analysis can be performed by employing the theory of beam on elastic foundation by using $k$ and $k^{\prime}$ from the calculation of Hardiyatmo Method [15]. The value of $k$ is for slabs without piles and $k$ ' is for slabs with piles. Modulus of subgrade reaction is defined as:

$$
k=\frac{q}{\delta}
$$

Where $k$ is the modulus of subgrade reaction, $q$ is the intensity of soil pressure, and $\delta$ is the deflection.

Modulus of subgrade reaction is determined from the relationship between load per unit area of slab and average deflection or settlement of slab due to point load on slabs without piles. The average value of modulus of subgrade reaction (k) was $222 \mathrm{kN} / \mathrm{m}^{3}$, taken from a linear curve of the relationship between pressure and deflection of the slab as shown in Figure 6.

The installation of piles will affect the modulus of subgrade reaction values. The modulus of sub-grade reaction by considering the effect of the pile support on resisting vertical displacement of the piles is called the equivalent modulus of subgrade reaction ( $\left.k^{\prime}\right)$. Equivalent modulus of subgrade reaction can be determined using Hardiyatmo Method [15] and expressed by Equation (9).

$$
k^{\prime}=k+\Delta k
$$

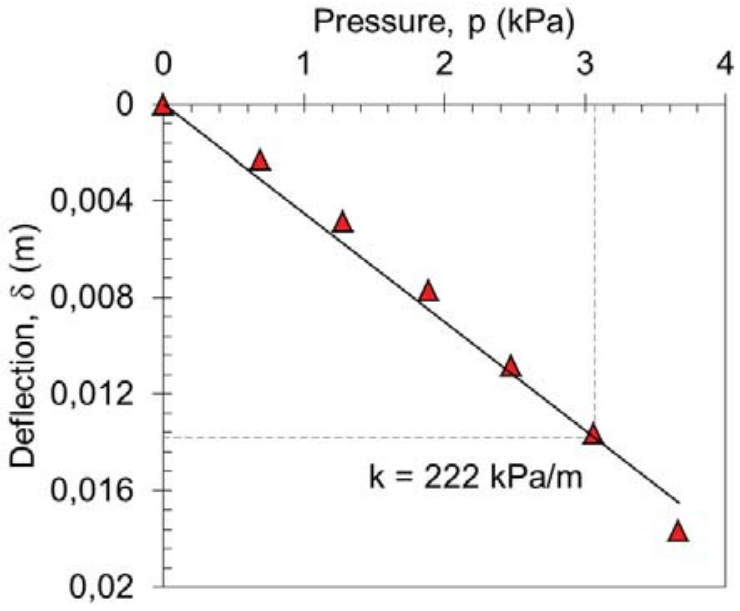

Figure 6: The Modulus of subgrade reaction values

The increase in modulus of subgrade reaction ( $k$ ) was due to the installation of piles with the same distances (Equation 10). The ultimate unit friction resistance on the pile shaft $\left(f_{s}\right)$ could be taken from the results of tensile tests on piles.

$$
\Delta k=\frac{\delta_{o} A_{s}}{\delta^{2} s^{2}} f_{s}
$$

Where $\delta_{0}$ is the relative displacement between pile and soil, $\delta$ is the plate deflection, As is the surface area of the pile shaft, and $s$ is the pile spacing.

Pile support affects the increase in the modulus of subgrade reaction values $(\Delta k)$. The increase in modulus of subgrade reaction due to the installation of piles can be employed as in Equation 10. If using the ratio of $\delta / \delta_{0}$ $=0.31$ as in Figure 5 and ultimate frictional resistance value (fs) from the tensile test results of $0.86 \mathrm{kPa}$ in Figure 4 , the average $\Delta \mathrm{k}$ was $436 \mathrm{kN} / \mathrm{m} 3,776 \mathrm{kN} / \mathrm{m}^{3}$, and $1.087 \mathrm{kN} / \mathrm{m} 3$, so that $\mathrm{k}^{\prime}$ increased to $658 \mathrm{kN} / \mathrm{m}^{3}, 998 \mathrm{kN} /$ $\mathrm{m}^{3}$, and $1.309 \mathrm{kN} / \mathrm{m}^{3}$ respectively for $L_{p} 15 \mathrm{~cm}, 25 \mathrm{~cm}$, and $35 \mathrm{~cm}$. Figure 7 shows the comparison between calculated and observed slab deflection on point of loading. The deflection of the slab with piles from the results of Hardiyatmo Method was approximately equal to the observations.

\section{Test Results of Pile Group due to Embankment}

One of the embankment load test results on the slab model with pile reinforcement can be seen in Figure 8. Stages of loading were done every day, loading was done by unloading and reloading. In addition to a longer loading time, preloading with loading-unloading system could reduce the compression of peat soil. Multiplication of height and weight of volume produced pressure value. The relationship between the settlement and the pressure obtained is shown in Figure 8b. 


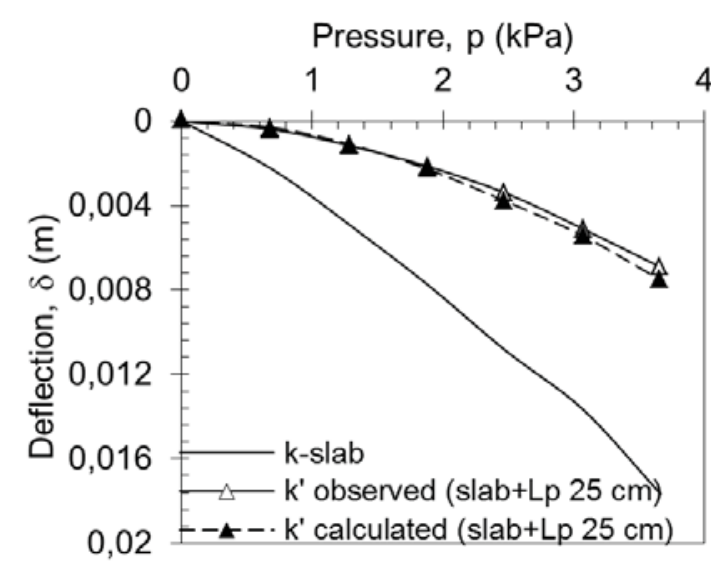

Figure 7: The comparison between calculated and observed deflection

(a)

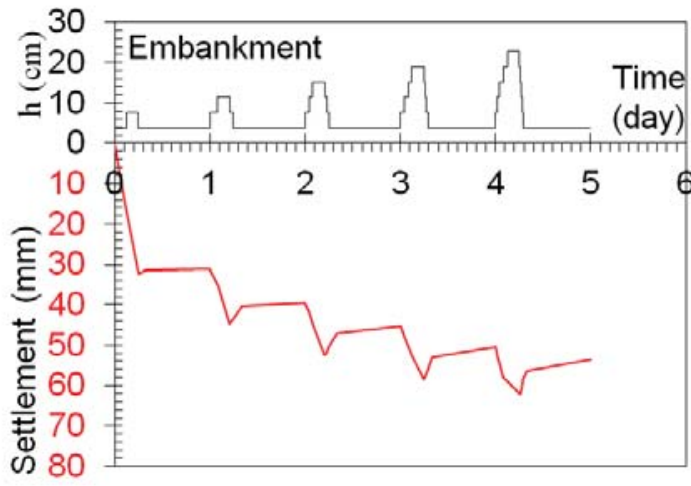

Pressure $(\mathrm{kPa})$

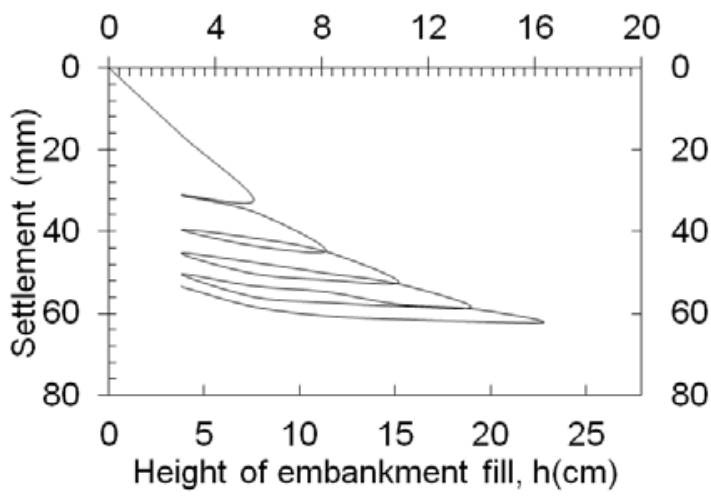

Figure 8: The settlement in the center of embankment on slabs with $15 \mathrm{~cm}$ monolithic piles:

(a) The relationship of time and settlement;

(b) The relationship between pressure and settlement
The same increase in pressure resulted in smaller settlement. This is because of the stages of loading and preloading with loading-unloading method; this result was similar for all five types of testing (Figure 9). Length of piles and pile connection system with slabs also affected the compression behavior of peat soil. Longer and monolithic piles generated smaller settlement.

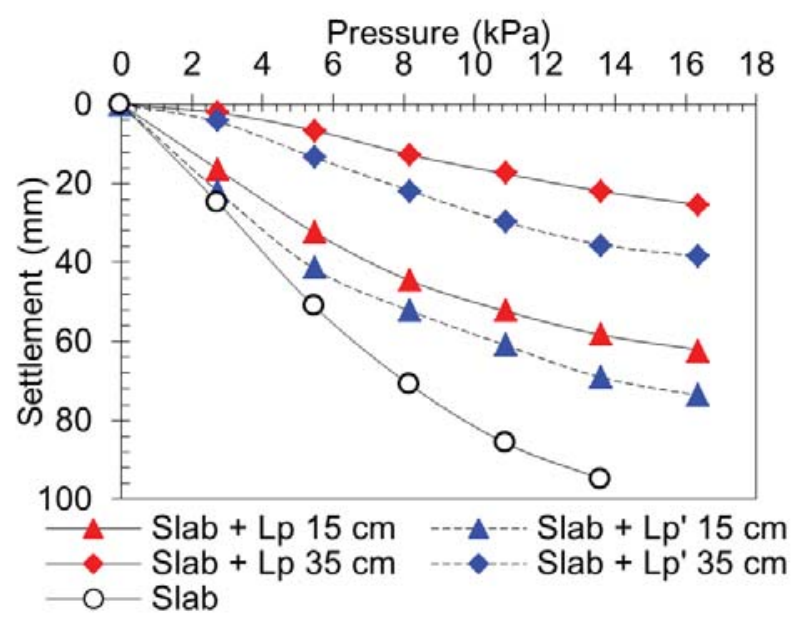

Note: $L p=$ Length of monolithic pile, $L p^{\prime}=$ Lenght of non-monolithic pile

Figure 9: The relationship between pressure due to embankment and settlement at the center of embankment

Monolithic piles with slabs could reduce the settlement up to $37 \%$ and $84 \%$ respectively for piles with $L p 15 \mathrm{~cm}$ $(\mathrm{Lp} / \mathrm{H}=0.3)$ and $35 \mathrm{~cm}(\mathrm{Lp} / \mathrm{H}=0.7)$, while the reduction of the settlement for non-monolithic piles with slabs was by $23 \%$ and $71 \%$ for $\mathrm{Lp} / \mathrm{H}=0.3$ and $\mathrm{Lp} / \mathrm{H}=0.7$. The reduction of settlement in monolithic piles to non-monolithic piles with slabs was $18 \%$ for $\mathrm{Lp} / \mathrm{H}=0.3$ and $45 \%$ for piles $L p / H=0.7$, where $H=$ Thickness of peat.

\section{Results of Consolidation Settlement Analysis}

Settlement due to embankment load on slabs without piles and slabs with piles were analyzed using FEM, Asaoka Method, and hyperbolic method.

FEM used Plaxis program based on peat parameters obtained from the results of laboratory tests and some other references. The collection of data of peat soil material, concrete pile, concrete slab, and embankment of iron bars is described in Table 1.

The properties of materials used as input to Plaxis $2 \mathrm{D}$ program are as shown in Table 1 . The elevation of ground water levels was parallel to the surface of peat soil. The construction of embankment on peat soil with slab-supported piles was analyzed using a plane strain model. The model of construction was symmetrical so that only half of the width was modelled (Figure 10a). The number of elements used was 15 nodes. The units of the basic parameters used were $\mathrm{m}$ for length, $\mathrm{kN}$ for force, and day for a time. The width of geometry model 
was $0.55 \mathrm{~m}$ taken from the half-width of the testing box in the laboratory. The stage of the calculation was done with the consolidation stage of each construction phase of the embankment with times following the time of observation in the laboratory. The results of analysis indicated the total displacement in the same embankment load stage as in Figure 10b.

Table 1: Material properties

\begin{tabular}{|c|c|c|}
\hline Parameter & Name & Value \\
\hline A. Peat & Model & Mohr-Coulomb \\
\hline Type of material & Type & Drained \\
\hline Soil unit weight & $\gamma_{\text {sat }}$ & $10.75 \mathrm{kN} / \mathrm{m}^{3}$ \\
\hline Permeability & $\mathrm{k}_{\mathrm{v}}=\mathrm{k}_{\mathrm{x}}$ & $0.879 \mathrm{~m} / \mathrm{day}$ \\
\hline Cohesion & $\mathrm{c}$ & $2.8 \mathrm{kPa}$ \\
\hline Friction angle & $\varphi$ & $33.22^{\circ}$ \\
\hline Young's modulus & $\mathrm{E}$ & $28.86 \mathrm{kPa}$ \\
\hline Poisson's ratio & $\mathrm{v}$ & 0.311 \\
\hline Dilatancy angle & $\Psi$ & 3.22 \\
\hline B. Embankment & Model & Linear elastic \\
\hline Type of material & Type & Non-porous \\
\hline Unit weight & $\gamma$ & $71.62 \mathrm{kN} / \mathrm{m}^{3}$ \\
\hline Young's modulus & $\mathrm{E}$ & $605 \mathrm{kPa}$ \\
\hline Poisson's ratio & $\mathrm{v}$ & 0.15 \\
\hline C. Concrete slab & Model & Elastic \\
\hline Normal stiffness & $\mathrm{EA}$ & $509,098.795 \mathrm{kN} / \mathrm{m}$ \\
\hline flexural rigidity & $\mathrm{El}$ & $16.970 \mathrm{kNm}{ }^{2} / \mathrm{m}$ \\
\hline weight & $\mathrm{w}$ & $0.489 \mathrm{kN} / \mathrm{m} / \mathrm{m}$ \\
\hline D. Concrete pile & Model & Elastic \\
\hline Normal stiffness & $\mathrm{EA}$ & $77,016.324 \mathrm{kN} / \mathrm{m}$ \\
\hline flexural rigidity & $\mathrm{El}$ & $1.9254 \mathrm{kNm}{ }^{2} / \mathrm{m}$ \\
\hline weight & $\mathrm{w}$ & $0.077 \mathrm{kN} / \mathrm{m} / \mathrm{m}$ \\
\hline
\end{tabular}

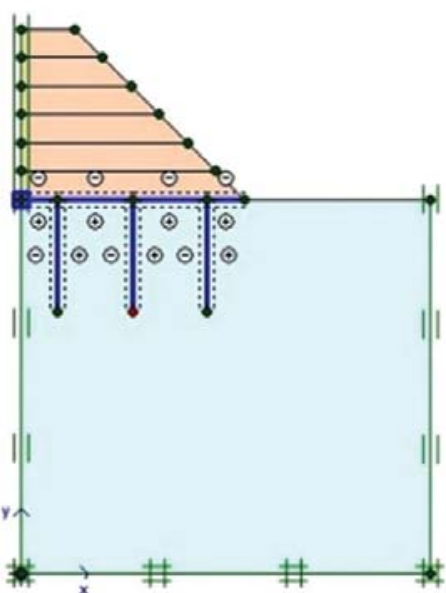

(a)

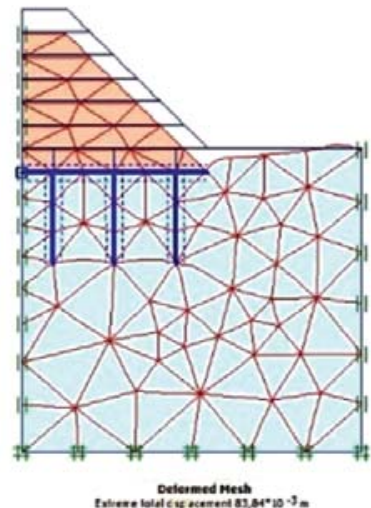

(b)
Figure 10: (a) Input geometry; (b) Total displacement due to embankment on slabs with piles
Figure 11 shows the comparison between the results of FEM and the observations on slabs without piles and slabs with piles Lp $15 \mathrm{~cm}$. The slabs without piles indicated that the results of FEM were almost similar to the observation, while the slabs with piles indicated that the settlement at the beginning of embankment was in agreement with the observations. However, the further embankment indicated that the values of settlement as a result of analysis were greater than that of the observations.

The comparison of the results of FEM, Asaoka Method, and hyperbolic method with observations for the slabs without piles and with piles are shown in Figure 12 and Figure 13. The estimation of settlement of Asaoka and hyperbolic methods employed Equations 2 and 3 . In general, the analysis of the three methods indicated a pattern of relationship between time and settlement that agreed with the observations. The settlement of slab with piles from the results of Asaoka Method was approximately equal to the observations, while the analysis of FEM and hyperbolic method generated greater settlement than the observations. Asaoka Method generated smaller settlement than other methods.

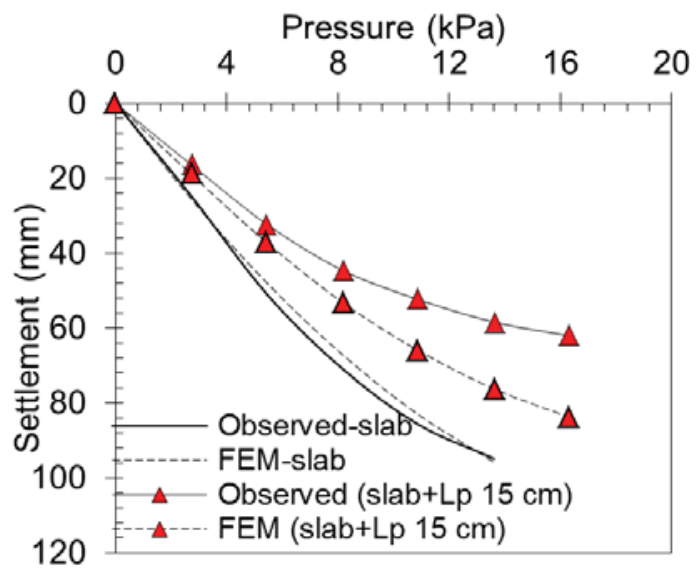

Figure 11: The comparison of the settlement between observations with FEM

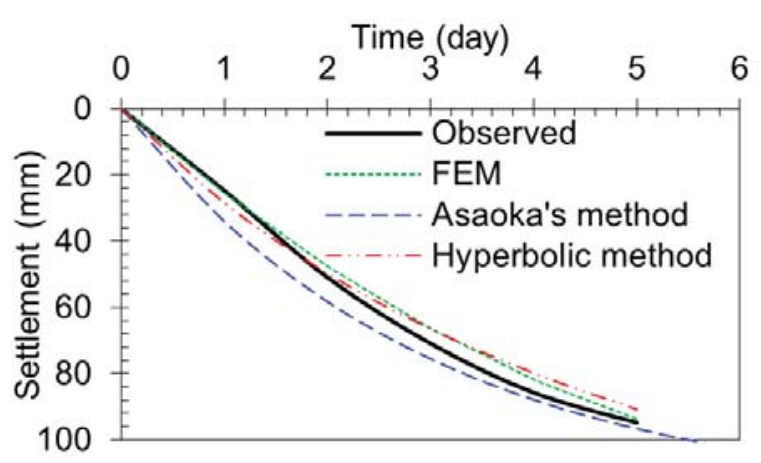

Figure 12: The relationship between time and settlement of slabs without piles 


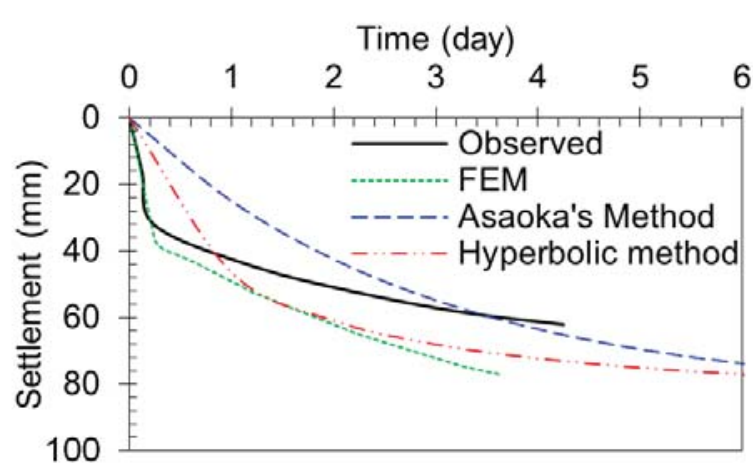

Figure 13: The relationship between time and settlement of slabs with piles

\section{CONCLUSION}

Soil samples tested were fibrous peat because they had an organic content of $99 \%>75 \%$ and fiber content of $35.21 \%>20 \%$. Peat deposits have high moisture content, low specific gravity, and low bulk density. The effective method for improvement of peat is preloading. It consists of applying a load in the form of the embankment. To produce a significant settlement, the embankment load was modelled from iron bars material. The unit weight of iron bars was approximately $71.62 \mathrm{kN} / \mathrm{m}^{3}$. One layer of the embankment load was given as high as of $h$ $=38 \mathrm{~mm}$, equivalent to the pressure $(\sigma)$ of $2.72 \mathrm{kPa}$. The use of iron bars as an embankment model gives a significant impact on the settlement for a laboratory smallscale model.

Stages of loading were done every day, loading was done by unloading and reloading. In addition to a longer loading time, preloading with loading-unloading system could reduce the compression of peat soil. Multiplication of height and weight of volume produced pressure value. The same increase in pressure resulted in smaller settlement.

Length of piles and pile connection system with slabs also affected the compression behavior of peat soil. Longer and monolithic piles generated smaller settlement. Piles installed on embankment-supporting slabs could increase modulus of subgrade reaction.

Estimation of settlement using Asaoka Method is close to the settlement from the results of observations, while the results of FEM and hyperbolic method are still greater than the results of observations.

\section{ACKNOWLEDGEMENTS}

The authors would like to thank the head and the technicians of the Soil Mechanics Laboratory of Gadjah Mada University for their help during the experimental work. Great appreciation is also given to Ministry of Research, Technology and Higher Education of the Republic of Indonesia for the financial support.

\section{REFERENCES}

1. Al-Ani, H., Oh, E., \& Chai, G. (2013). Characteristics of embedded peat in coastal enviromental. International Journal of Geomate, 5(1), 609-618.

2. Kazemian, S., Prasad, A., Huat, B. B., \& Barghchi, M. (2011). A state of art review of peat: Geotechnical engineering perspective. International Journal of Physical Sciences, 6(8), 1974-1981.

3. Vakher, M. (2004). Soil Model Selection in EarthBased Extreme Region with Peat Foundation under Large Loading Area. In Engineering, Construction, and Operations in Challenging Environments: Earth and Space 2004, (pp. 767-774).

4. Toh, C. T., Chee, S. K., Lee, C. H., \& Wee S. H. (1994). Geotextile-bamboo fascine mattress for filling over very soft soils in Malaysia. Geotextiles and Geomembranes, 13(6-7), 357-369.

5. Porbaha, A., Hanzawa, H., \& Kishida, T. (2000). Analysis of a failed embankment on peaty ground. Slope Stability 2000, (pp. 281-293).

6. Mesri, G., Stark, T. D., Ajlouni, M. A., \& Chen, C. S. (1997). Secondary compression of peat with or without surcharging. Journal of Geotechnical and Geoenvironmental Engineering, 123(5), 411-421.

7. Mesri, G., \& Ajlouni, M. (2007). Engineering properties of fibrous peats. Journal of Geotechnical and Geoenvironmental Engineering, 133(7), 850-866.

8. Waruwu, A., Hardiyatmo, H. C., \& Rifa'l, A. (2016). Compressive behavior of Bagansiapiapi-Riau Peat in Indonesia. Electronic Journal of Geotechnical Engineering, 21(16), 5217-5227.

9. Kamao, S. (2016). Creep and relaxation behavior of highly organic soil. International Journal of Geomate, 11(25), 2506-2511.

10. Susanti, R. D., Maulana, \& Waruwu, A. (2017). Bearing capacity improvement of peat soil by preloading. ARPN Journal of Engineering and Applied Sciences, 12(1), 121-124.

11. Rowe, R. K., \& Li A. L. (2005). Geosynthetic-reinforced embankments over soft foundations. Geosynthetics International, 12(1), 50-85.

12. Vakher, M. (2000). Load-Deformation Performance of Peat Soil Under Large Concrete Plates. In Geotechnical Measurements: Lab and Field (pp. 44-55).

13. Liu, H. L., Ng, C. W., \& Fei, K. (2007). Perfomance of a geogrid-reinforced and pile-supported highway embankment over soft clay: case study. Journal of Geotechnical and Geoenvironmental Engineering, 133(12), 1483-1493.

14. Diana, W., Hardiyatmo, H. C., \& Suhendro, B. (2017). Effect of pile connections on the performance of the nailed-slab system on the expansive soil. International Journal of Geomate, 12(2), 134-141. 
15. Hardiyatmo, H. C. (2011). Method to analyze the deflection of the nailed-slab system. International Journal of Civil \& Environmental Engineering, 11(4), 22-28.

16. Puri, A., Hardiyatmo, H. C., Suhendro, B., \& Rifa'l, A. (2013). Pile Spacing and Length Effects Due To the Additional Modulus of Subgrade Reaction of the Nailed-Slab System on the Soft Clay. In Proc. of 13th Symposium on Quality in Reseach (QiR) (pp: 10321310).

17. Asaoka, A. (1978). Observational procedure of settlement prediction. Soil and Foundations, 8(4), 87101.

18. Huat, B. B., Hoe, N. C., \& Munzir, H. A. (2004). Observational methods for predicting embankment settlement. Pertanika J. Sci. Technol., 12(1), 115-128.

19. Li, C. (2014). A simplified method for prediction of embankment settlement in clays. Journal of Rock Mechanics and Geotechnical Engineering, 6(1), 61-66.

20. Tan, T. S., Inoue, T., \& Lee, S. L. (1991). Hyperbolic method for consolidation analysis. Journal of Geotechnical Engineering, 117(11), 1723-1737.

21. Brinkgreve, R. B. J. (2002). PLAXIS 2D - Version 8", A. A. Balkema Publishers, Netherlands.

22. Ryltenius, A. (2011). FEM Modelling of piled raft foundations in two and three dimensions", Master's Dissertation, Geotechnical Engineering, Department of Construction Sciences, Lund University, Swedia. 